\title{
IMPROVING THE QUALITY OF EDUCATION IN THE COVID-19 ERA THROUGH THE IMPLEMENTATION OF ONLINE LEARNING RESOURCES WITH POE2WE MODEL ON PARABOLIC MOTION
}

\author{
Vina Serevina ${ }^{*}$ Raida $^{2}$ \\ 1,2Magister of Physic Education, State University of Jakarta, Jakarta, Indonesia \\ *vina.serevina77@gmail.com
}

\begin{tabular}{l}
\hline \hline Article Info \\
\hline Article history \\
Received: October 22, 2020 \\
Revised: December 3, 2020 \\
Accepted: December 8, 2020 \\
\hline
\end{tabular}

\section{Keywords:}

Improving the quality of education;

Online learning resource; Quality of education.

\begin{abstract}
The Covid-19 pandemic has affected all aspects of life, also education. Educators worldwide have had to adapt the situation by developing online learning models to keep education running. The present study aims at developing online learning resources using websites and the POE2WE model of parabolic motion material. The POE2WE model was represented as six stages of online learning that includes Prediction, Observation, Explanation, Elaboration, Write, and Evaluation. 30 students of 10th grade of a high school in Indonesia participated in this study. The ADDIE model (analyzing, designing, developing, implementing and evaluating) used in this study representing its R\&D methodology with the evaluating stage carried out in every other stage. The online learning model validated with three different experts, namely media, material, and learning expert resulting in $89.40 \%, 89.31 \%$, and $86.71 \%$. The results indicated that the model was valid and reliable. Pre-test and post-test conducted to investigate the effects of the learning model, which resulted in $40.03 \%$ and $82.73 \%$ respectively, with the $\mathrm{N}$ gain mean result in high category (0.71). It can conclude that the online learning model developed in this study was effective in increasing students understanding of parabolic motion.
\end{abstract}

\section{INTRODUCTION}

With the coronavirus pandemic, people all over the world have seen the significant impacts on almost every aspect of life including education. As the pandemic has changed how students are educated, the method of face-to-face learning turns into distance learning (O'brien et al., 2020). Policy on learning adjustments have been made by Education Ministry of Indonesia through Circular Number 4 of 2020 on Implementation of Education Policy in Emergency during COVID-19 spread. With learning takes place via interaction using personal computers or through the internet, e-learning soft-wares have been found to help students learn during the pandemic (Irmayani et al., 2018). As a way to mimic face-to-face learning, students and teachers participate in a lesson at the same time using group chats on social media such as WhatsApp (WA), Telegram, Google Classroom, G-meet, Web-ex, and Zoom. In this unprecedented time, technology plays a major role in learning activities, and social media applications will help students to learn easily and efficiently everywhere (Mohamad 
et al., 2016). The aim of this research was to develop online learning resources using websites and the POE2WE model of parabolic motion material.

The policy on learning adjustments during pandemic indicates the quality of education must remain a top priority, because the level of education quality is considered a bridge to improve one's quality of life (Bankole \& Assefa, 2017). To improve the quality of education will greatly affect a person's life in the future. Educational strategies then will play an important role in improving the quality of education, and one of them is the POE2WE learning model (Predict, Observation, Explanation, Elaboration, Write, Evaluation).

Previous research by John W. Chow et al. on web-based videos investigated students' direct experience in the learning of projectile motion. The kinematic of motion, which is one of the techniques used to analyze motion in biomechanics, was included in mathematical skills (Chow \& Carlton, 2020). From this study, web-based learning as a technology implementation to support learning process was found to create skills with simulations on the web. As to the need to implement the web-based learning, Figure 1 was the results of needs analysis conducted for the present study.

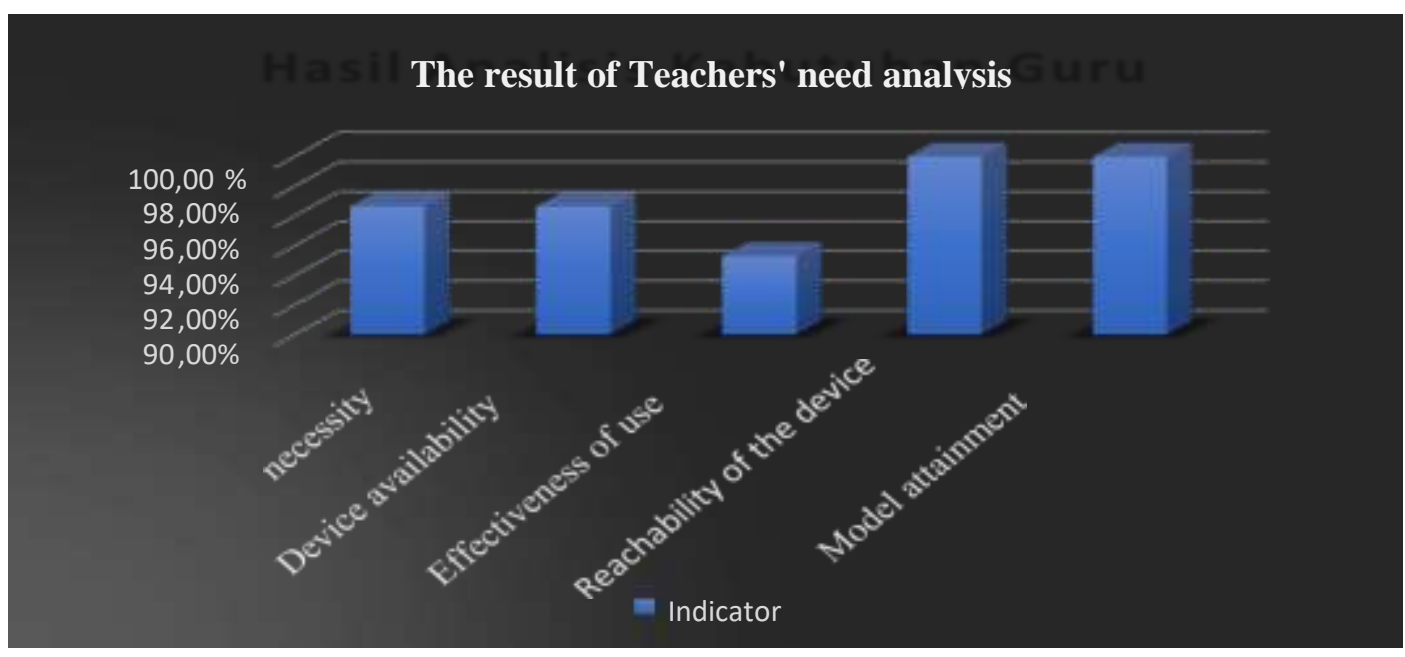

Figure 1. The result of the teachers' need analysis.

Figure 1 shows the result of needs analysis from teacher's perspective. It can be seen clearly through the high percentages across the five indicators that there is a need to improve education quality through development of online learning resources.

As contained in the journal, infographic media is indispensable and can be developed. If graphical information is composed of drawings and graphics, students would prefer it. Overall, the results of publication to all teachers who became respondents found that infographic media is very necessary and feasible to be developed, especially for the lesson of Physics on the concept of kinematics motion. Because in general the package book that discusses the material, contains too many texts or sentences that can make students' cognitive 
loads heavier. In addition, high school students are Z generation who love visual (Aptiyanti et al., 2020). As we can see from the Figure 1, the necessity is up to $96 \%$, so it can be called accurate if we compare to the previous research that said it very necessary and feasible to be developed. The effectiveness is up to $92 \%$, according to the previous research, these kind of media can help students to relieve students' cognitive. Besides, the result of student's needs analysis can be seen at figure 2 .

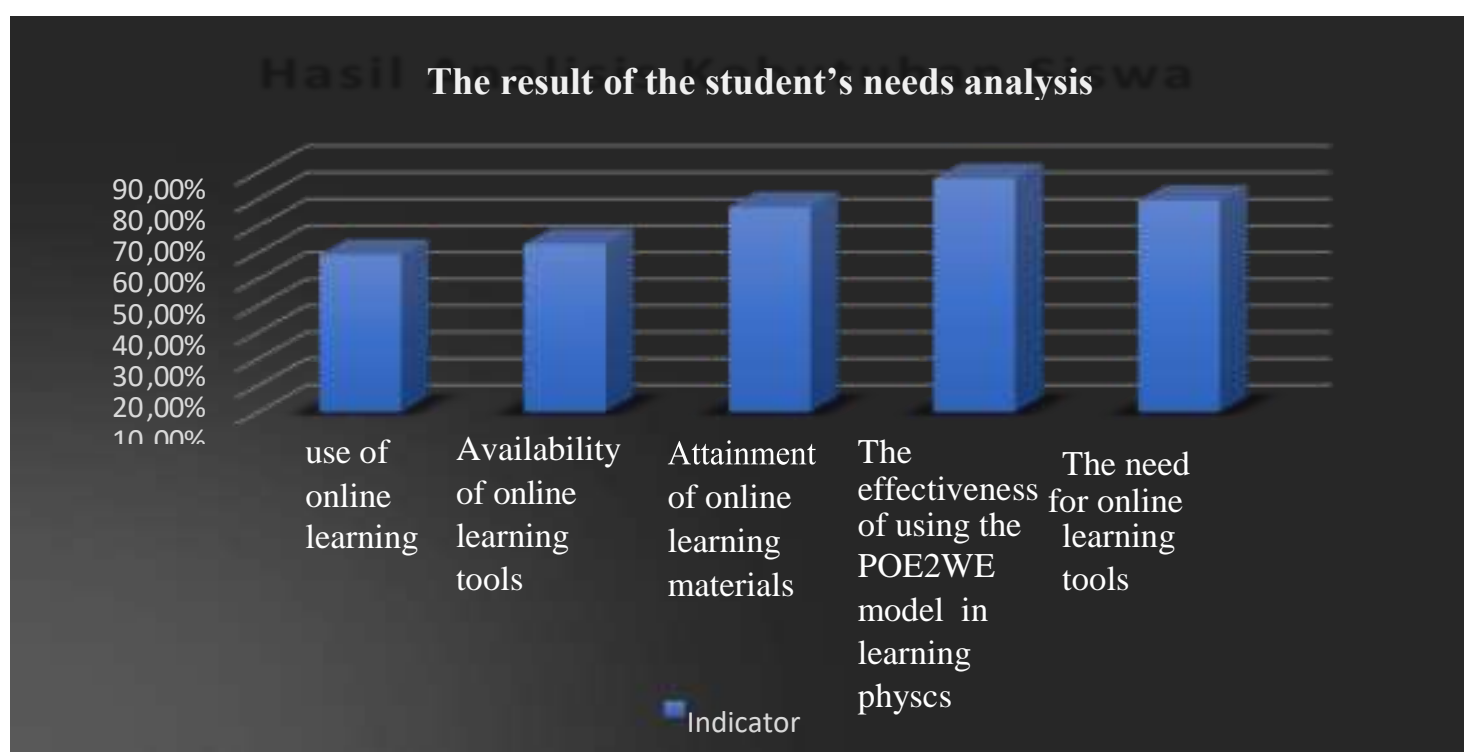

Figure 2. The Result of student's needs analysis

Figure 2 shows the result of needs analysis from student's perspective. Across the five indicators, it can be inferred that there is a need to conduct the research on the topic of online learning.

As written in the previous research, the results of the study show that the role of information and communication technology has not been maximized in basic physics learning effectively and efficiently for both lecturers and students, while the demands of 21 st-century learning are expecting the role of ICT (information, communication and technology) in learning, especially by using hybrid learning. Furthermore, the recommendation of this research is to design a hybrid learning model that combines digital technology and mobile learning technology as a new challenge in 21 st-century learning (Ma'ruf et al., 2020). As we can see from the Figure 2, the effectiveness of using the POE2WE model in learning physics is exceeding $80 \%$, in accordance with the previous research, role of information and communication technology has not been maximized. The increase in effectiveness in the roles of both students and teachers indicates that the use of POE2WE media can be said to be successful in overcoming problems from previous research. The need for online learning tools is up to $75 \%$ and for the availability of online learning tools almost reach $60 \%$ stated that the need for the role of ICT is still high. 


\section{LITERATURE REVIEW}

\subsection{Web-based learning}

Learning is the most important part in improving the quality of education (Herdiani, 2020), and the improvement depends on education system (Kulkarni et al., 2020). Evaluation also plays an important role, as a way to determine the effectiveness and efficiency of learning process, teacher quality and student learning outcomes. Together the system and evaluation are needed to improve the quality of education. Improvement of the quality of education can be measured through learning process and learning outcomes across their effectiveness, efficiency and productivity. Learning process, especially during the COVID-19 pandemic is very dependent on learning model, learning media and learning resources. In education, teachers, students and technology are interrelated (Abdinazarovna, 2019). When the quality of education improves, so do those three aspects. Technology in learning process can make use of websites or online forums where communication and discussion take place (Leontev et al., 2018).

Web-based learning as a part of e-learning employs the internet, allowing students to learn throughout the media (Panigrahi et al., 2018). Learning through a website can actually mimic the actual classroom since the same materials and teaching instruction are employed thanks to the technology itself. Students can also explore a great amount of additional learning resources within the media (Yuda et al., 2019). It can be said that the media helps not only teachers in knowledge transfer (Serevina et al., 2020), also the students in having the access to a wealth of learning resources especially during the time when they cannot meet their teachers.

\subsection{POE2WE Learning Model}

The POE2WE model (Predict, Observation, Explanation, Elaboration, Write, Evaluation) which can be applied in online-based learning enables students to become active in accessing knowledge (Herdiani, 2020). The POE2WE learning model is developed from the combination of three learning models i.e. the POE learning model, the TTW learning model, and the constructivist learning model (Nana \& Surahman, 2019). POE2WE can also help students practice their scientific abilities (Nana et al., 2014). Scientific ability is very important for students when carrying out learning activities. The POE2WE model hence allows students to (i) build their knowledge actively, (ii) make predictions about a phenomenon, (iii) observe certain materials by applying laws or formulas through experiments or simulations, (iv) describe the experiments and simulations, ( $v$ ) apply it in everyday life, and (vi) write and 
evaluate the learning results. All of these learning stages enable students to gain in-depth knowledge. The projectile motion can be seen at Figure 3.

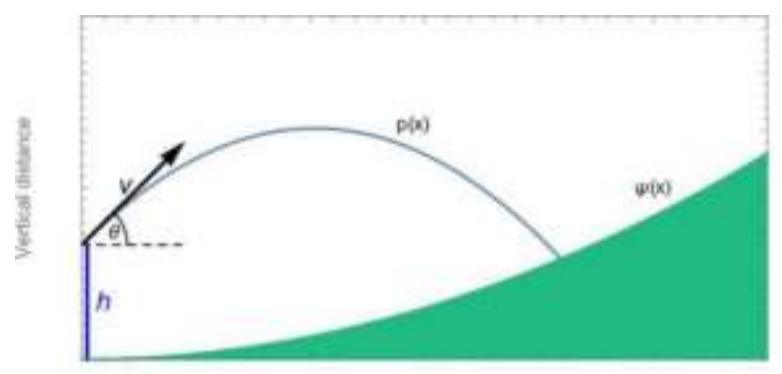

Figure 3. The projectile motion (Henelsmith, 2016).

\subsection{Parabolic Motion}

Parabolic motion is a combination of regular straight motion (GLB) on the $X$ axis and regular changing straight motion (GLBB) on the $Y$ axis with constant acceleration [26]. If a bullet is fired and inclines upward from point 0 with an elevation angle to a horizontal plane, this movement of the bullet has a parabolic trajectory in the vertical plane. During the movement of this parabola, it is only affected by the earth's force field in the form of its gravity (Henelsmith, 2016).

The equation of parabolic motion is as follows:

1. The motion in the $x$-direction is described by

$$
\begin{gathered}
x^{\prime \prime}(t)=0 ; \\
x^{\prime}(t)=v \cos \theta ; \\
(t)=v t \cos \theta \ldots \ldots \ldots \ldots
\end{gathered}
$$

2. The motion in the y-direction is described by

$$
\begin{gathered}
y^{\prime \prime}(t)=-g ; \\
y^{\prime}(t)=-g t+v \sin \theta ; \\
(t)=-1 / 2 g t^{2}+v t \sin \theta+h .
\end{gathered}
$$

3. Solving for $t$ in (1) and substituting into (2) yields

$$
t=x / v \cos \theta \text {. }
$$

4. The motion of the projectile

$$
\begin{array}{r}
(x)=h+v \sin \theta(/ v \cos \theta)-1 / 2 g(x / v \cos \theta)^{2} \\
h+x \tan \theta-g x^{2} / 2 v^{2} \sec ^{2} \theta \ldots \ldots \ldots .(4)
\end{array}
$$

\section{METHODS}

This research was conducted from March to June 2020 and the participants were grade 10 students from a public high school in Tangerang Regency, Indonesia. Research \& Development (R\&D) methodology was applied using the ADDIE model (Analysis, Design, 
Development, Implementation and Evaluation). The five stages of the model were described below.

\subsection{Analysis}

As the first step, a needs analysis from both students and teachers was carried out to gather information related to the problem in the study. The results were shown in Figures 1 and 2, giving indication of the need for a research to develop online learning resources using a website and the POE2WE model on parabolic motion material.

The need analysis result shows that the learning media in the form of video is following the character of students and learning objectives. In developing this learning media, preliminary media experts, material experts, and physics teachers did the validation. The improvement results from this validation became a design that was tested on a small group to determine student responses. From the results of a thorough evaluation taking into account the validation of experts, teachers, and student responses, it implies that this media is appropriate for use. In the next stage of the study, the effectiveness and practicality of this learning medium will improve student learning achievement (La Aca et al., 2020). Blended learning refers to a combination of face-to-face learning, including but not limited to teachers and online learning (Syakur et al., 2020). This study uses a reference method from previous research in increasing the effectiveness of using blended learning.

\subsection{Design}

A design evaluation was carried out to determine the learning model that suites target classes. At this stage a lesson plan and a website are designed.

\subsection{Development}

With design already prepared, the next step is to develop the lesson plan from which follows the development of the website based on the lesson plan.

\subsection{Implementation}

The next stage allows the implementation of the lesson plan through the website (vinnarrai.com)

\subsection{Evaluation}

Evaluation is actually applied in every stage of ADDIE model, allowing researcher to reflect on the strengths and weaknesses of the model.

Once the learning model is ready to use, expert validation is conducted as part of the development of learning resources using a website with POE2WE model on parabolic motion learning. In the next part the results of the expert validation are discussed.

\section{RESULT AND DISCUSSION}

\subsection{RESULT}

The current research discusses the use of an online learning tool with a website (vinnarrai.com) which can be accessed using student accounts. 
Table 1. Screenshots of the online learning resources

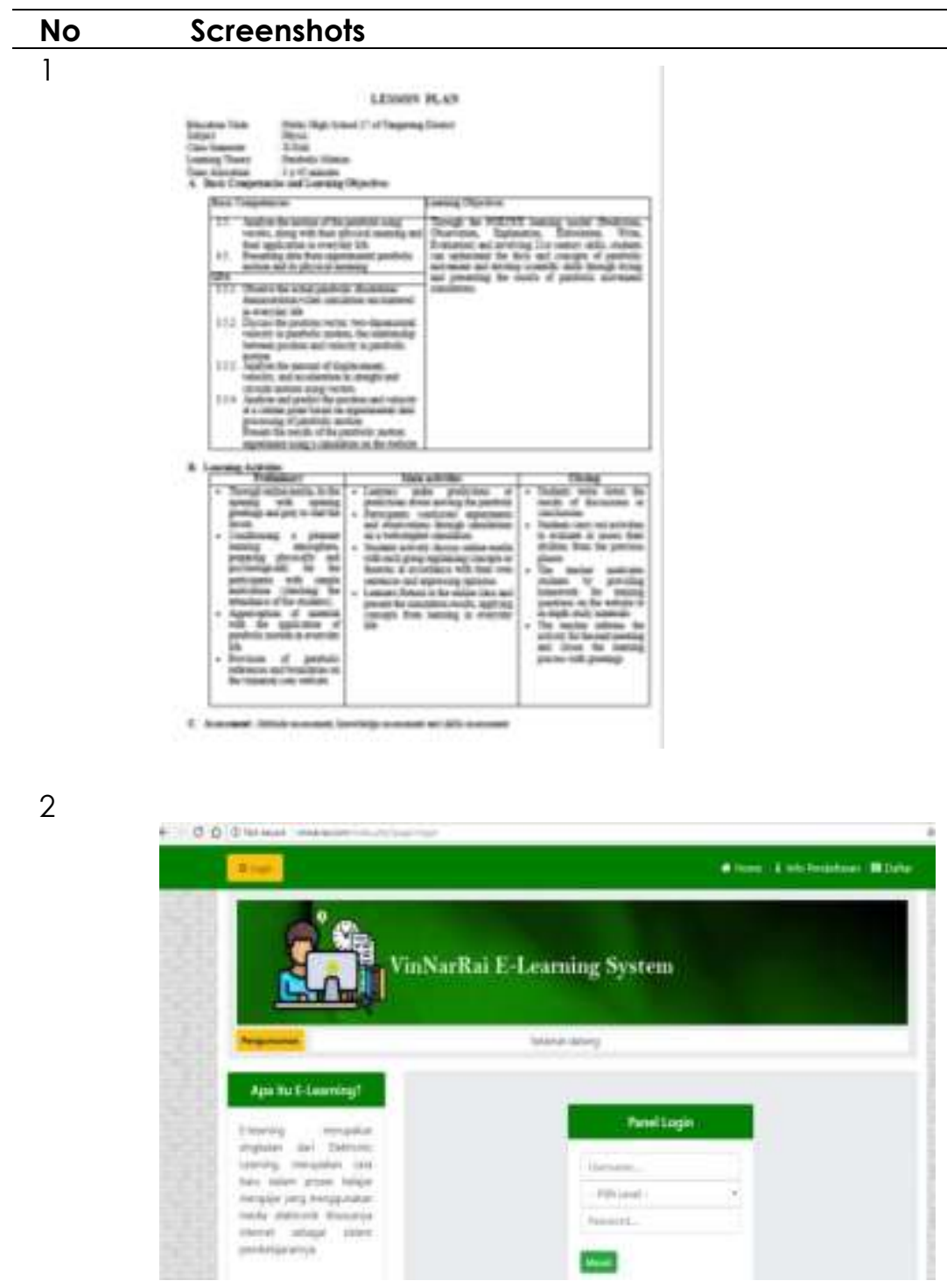

Information

Lesson Plan (RPP)

designed based

on the latest

national

curriculum

(Freedom of

Learning)

Website

vinnarrai.com

3

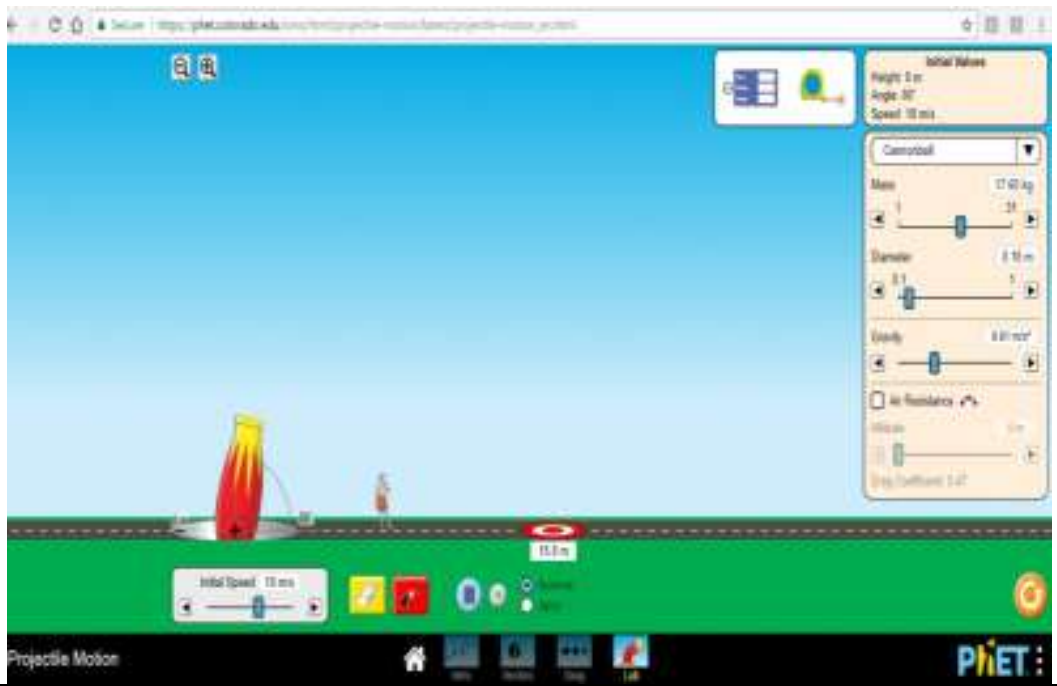

Web simulation of parabolic motion

\subsection{DISCUSSION}

The COVID-19 pandemic thrust learners and educators across the world into a new 
environment, in which e-learning became the foremost method of education. As the community is unsure about how this pandemic will persist, it is of paramount importance to embrace e-learning in physics education. The smartphone was explored as an educational tool; its advantages in the classroom and its range of sensors and apps for use in the laboratory were identified (Parker, 2020). Seeing the current conditions in learning makes us look for the best solutions in learning that students need. The use of existing technology can be as much as possible to help learning. Slightly different from previous studies using smartphones, the use of a web-based learning system is almost the same as a smartphone which is a medium of interaction. This media provides many benefits in the world of learning. The following steps of learning through a constructivist approach with the POE2WE model combined with the physics module of parabolic motion material:

1. Prediction

The Prediction stage allows children to make predictions about a problem from the questions in the physics module showing regularly-changing straight motion. A teacher will facilitate students with stimuli for making prediction or provide hypothesis of a problem in the student's worksheet.

2. Observation

At the Observation stage, students find out whether their initial hypothesis is correct or not. Here students should also be able to answer the question asked in the previous stage.

3. Explanation

The Explanation stage enables students to explain the truth between the initial predictions and the simulation results. At this stage students can discuss the results of the experiment in groups, followed with a class presentation. The role of the teacher at this stage is predominant, with teacher as a facilitator. In case of students' explanation is not in accordance with existing reality nor theory, teachers' role is to help students to explain.

4. Elaboration

At this stage students can relate the theory learned from learning materials with any aspects of their everyday life. A teacher can encourage students to find new concepts in life, so that students can more easily understand the concept explained in the materials.

5. Write

The writing stage is the stage where students write the conclusions drawn from the previous stages. Students can reflect on their ability to explain the knowledge from the series of stages

6. Evaluation

Evaluation stage (evaluation) is the stage to measure the knowledge, skills, and changes

IJEMI Vol.2, No.1, January 2021, pp. 13 28 
in the thinking process of students regarding the delivered material. At this stage students can practice their ability to use the same concept to complete various existing tasks.

Validation by experts using the Likert scale can be interpreted as Table2.

Table 2. Likert scale (Riduwan \& Akdon, 2013)

\begin{tabular}{ll}
\hline Average Score & Interpretation \\
\hline $0 \%-20 \%$ & Very bad \\
$21 \% 40 \%$ & bad \\
$41 \%-60 \%$ & moderate \\
$61 \%-80 \%$ & Good \\
$81 \%-100 \%$ & Very good \\
\hline
\end{tabular}

The Table 3 was the validation result of media, material and learning experts.

Table 3. Validation result from media experts

\begin{tabular}{lll}
\hline Aspect & Validator 1 & Validator 2 \\
\hline Design & $75.00 \%$ & $97.5 \%$ \\
Language & $85.00 \%$ & $95 \%$ \\
Core material & $84.00 \%$ & $100 \%$ \\
Average percentage & $81.30 \%$ & $97.5 \%$ \\
Overall percentage & $89.40 \%$ & \\
\hline
\end{tabular}

Based on the Table 3, the overall percentage from media experts shows that $89.40 \%$, which categorized as very good. This estimation is taken from design, language, and core material. This media is indeed a learning media that recently used in learning process, so it is accordance with the times (Astuti et al., 2020). The result from media expert's validation in this research relevant with statement from $\mathrm{F} \mathrm{N}$ Astuti, because the learning process in this research used media for learning on parabolic motion which was very good especially in design, language, and core material.

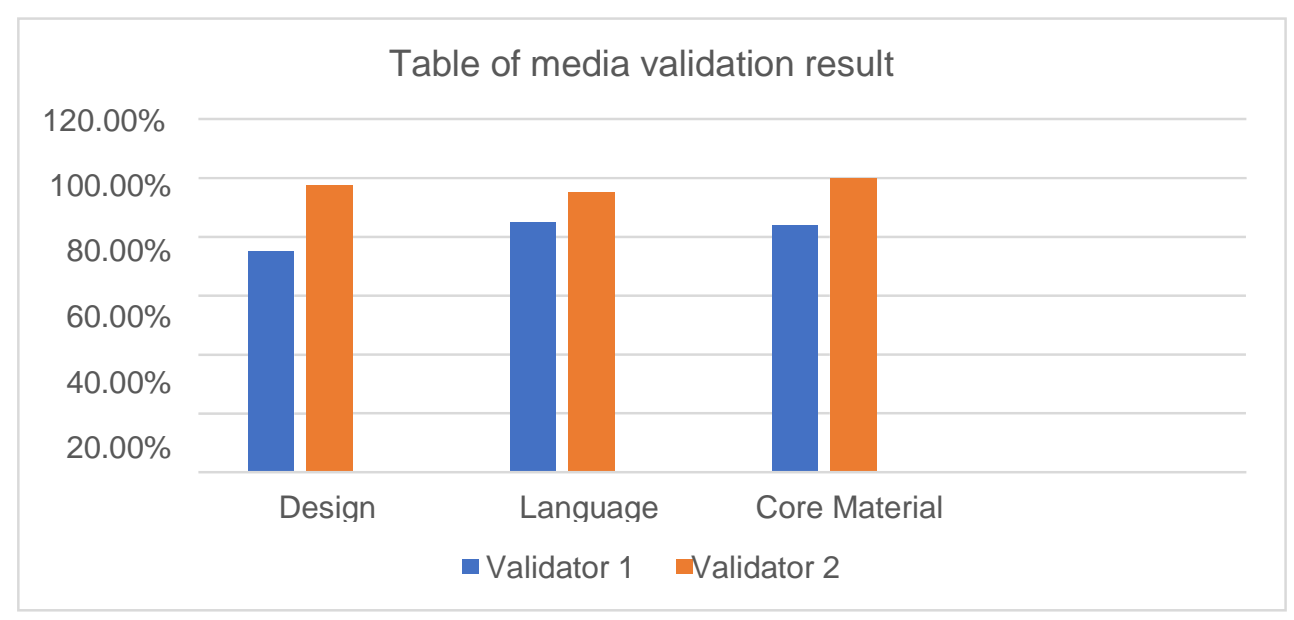

Figure 3. The result of the media experts' validation 
As to validation in media, Table 3 and Figure 3 show the results from two experts. The experts rated the material across three different aspects i.e. design, language and core material, and they had a high level of agreement ( $81.30 \%$ and $97.50 \%$ respectively). This is a very high level according to Likert scale as far as the overall agreement is concerned (89.40\%). The results thus indicate clear language used in the material, as well as clearly explained core material and well-designed material, which can be used as resources for learning the parabolic material.

Table 4. The result of material expert's validation

\begin{tabular}{lll}
\hline Aspect & Validator 1 & Validator 2 \\
\hline Content eligibility & $92.70 \%$ & $88.12 \%$ \\
serving eligibility & $89.06 \%$ & $81.02 \%$ \\
Language eligibility & $87.50 \%$ & $97.50 \%$ \\
Average percentage & $89.75 \%$ & $88.88 \%$ \\
Overall percentage & $89.31 \%$ & \\
\hline
\end{tabular}

Widyastuti et al. (2017) in their research said that assessment were conducted several times including revisions in case there were less obvious contents, such as improper concept, errors on writing the symbol, improper use of diction, etc. From the material validation, the score was 3.88 (very valid). In this research assessment were conducted many times, the result from material experts validation with the score $89,31 \%$ (very good). Actually the meaning of these material validations were the same but different reference for assessment.

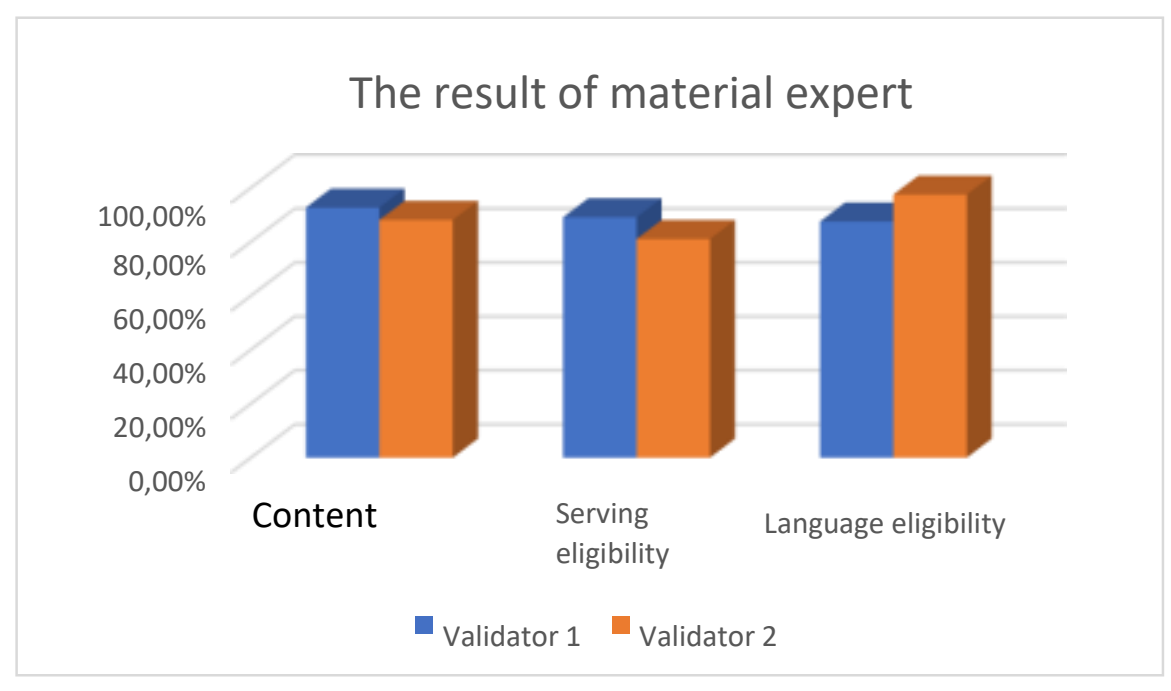

Figure 4. The result of material expert validation

Material validation is an instrument feasibility assessment procedure for generating agreements among expert through qualitative assessments (Saifudin, 2016). A material validity can be determined based on the accuracy and sensibility of the measurement results by experts using validation sheet (Arikunto, 2015). According to both of these statements, in this 
research there were 2 material experts who validated the material in this developed RPS (semester learning plan) with 8 learning videos, with the aspects of Content eligibility, Serving eligibility and Language eligibility.

Both Table 4 and Figure 4 show the results of validation from two experts in material.

Across the three aspects of material, the two experts had a high level of agreement (89.75\% and $88.88 \%$ respectively). The overall level of agreement $(89.31 \%$ ) can be considered as very high as to the Likert scale. The results of the expert validation thus indicates that the material can be used as online learning resources for learning the parabolic motion. The result of learning expert's validation can be showed at table 5 .

Table 5. The results of learning validation

\begin{tabular}{lll}
\hline Aspect & Validator 1 & Validator 2 \\
\hline Subject identity & $83.75 \%$ & $87.50 \%$ \\
Streak indicators and learning objectives & $85.00 \%$ & $80.00 \%$ \\
Learning materials & $85.00 \%$ & $85.00 \%$ \\
Selection of learning approaches & $93.33 \%$ & $100 \%$ \\
Learning activities & $80.00 \%$ & $93.00 \%$ \\
Selection of learning resources & $81.60 \%$ & $85.00 \%$ \\
Average percentage & $84.68 \%$ & $88.42 \%$ \\
Overall average percentage & $86.71 \%$ & \\
\hline
\end{tabular}

In Patresia's research, the result from learning experts validation obtained the average score 3.7, with category highly feasible (Patresia et al., 2002). Her research different aspects of assessment reference and standards with this research. Meanwhile in this research, the result from learning experts validation obtained the average score $86.71 \%$ which refer to the weight of the Likert scale rating and can also be interpreted as very good, the meaning that the experts agreed the online learning resources (RPS with 8 learning videos which developed) based on the identity of learning in the subjects were very good.

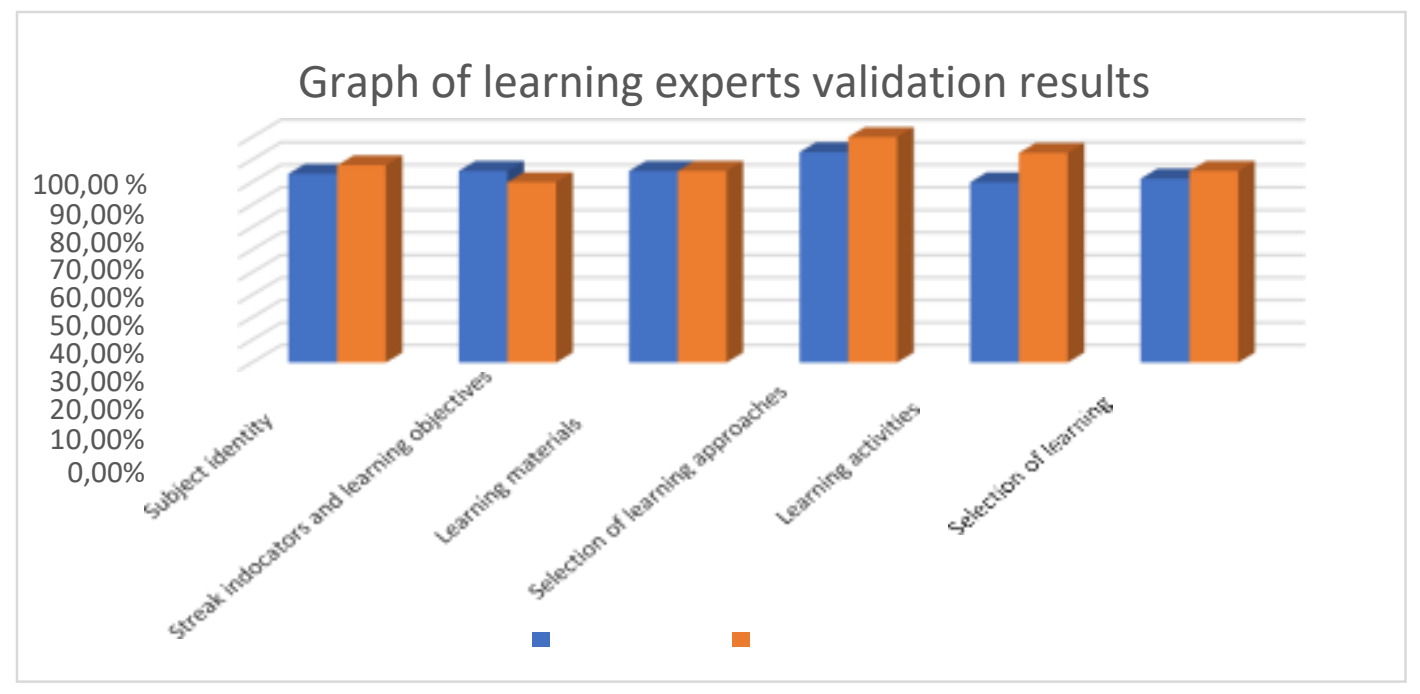

Figure 5. The result from the validation of learning experts 
Table 5 and Figure 5 showed the results of validation from two experts in learning. It can be seen that across six different aspects of learning the two experts had a high level of agreement ( $84.68 \%$ and $88.42 \%$ respectively). The overall agreement of $86.71 \%$ according to Likert scale can also be interpreted as very high, meaning that the experts agreed that the online learning resources developed based on the identity of the subjects were very good. It also indicates that the indicators and basic competencies are very compatible with the material of parabolic motion, whereas the learning material was considered very good. The choice of POE2WE learning approach was considered very appropriate and learning activities were considered very good, which also indicates a good selection of learning sources. Overall the expert validation shows that implementation of online learning resource as a means of improving the quality of education was suitable for use as material for learning parabolic motion during the Covid-19 pandemic.

The analysis of effectiveness in improving education quality used on the results of the pretest and posttest was to use $\mathrm{N}$-gain score (g). The $\mathrm{N}$-gain score was calculated by dividing the increase in actual average (G) by increasing the actual maximum mean value (Gmax). The calculation formula is as follows.

$\begin{aligned} \text { N-gain Score } & =\frac{G}{\text { Gmax }}=\frac{\text { Postest-Pretest }}{100-\text { Pretest }} \\ & \\ & \begin{array}{ll}\text { Table 6. Effectiveness degree of N-gain score [9] } \\ \hline \text { Mean N-Gain } & \text { Category } \\ \hline N-\text { Gain } \geq 0.7 & \text { High } \\ 0.7>N-\text { Gain } \geq 0.3 & \text { Medium } \\ 0.3>N-\text { Gain } & \text { Low } \\ \hline\end{array}\end{aligned}$

Table 7. Data of effectiveness degree of N-gain score

\begin{tabular}{lllc}
\hline $\mathrm{n}=30$ & & & \\
\hline Test & Mean & STD & $\mathrm{N}$-gain \\
Pre-test & 40.03 & 11.06 & 0.71 \\
Post-test & 82.73 & & \\
\hline
\end{tabular}

Throughout 10 essay questions with 30 students took both pre-test and post-test, as shown in Table 7 indicated an average score of $40.03 \%$ and $82.73 \%$ in the two respective tests. The standard deviation value was 11.06 and $\mathrm{N}$-gain was 0.71 . Wulandari et al. in their research said, the results of the pretest and posttest analysis using n-gain score showed the effectiveness of instructional materials score was 0,54 with the category from N-Gain Hake as moderate (Wulandari et al., 2020. In this research showed the average score of pre test $40.03 \%$ and the average score of post test $82.73 \%$, Then $\mathrm{N}$-gain score was 0.71 . So, the effectiveness of the result study in this research could be better, because of $\mathrm{N}$-gain score 
$0.71>0.54$. So that improving the quality of education by using pre test and post test on parabolic motion material and also implementation of POE2WE, based on the N-gain scale (Hake \& Richard, 1998) the data can be classified into high categories. The effectiveness score in high category indicating that the POE2WE model using the website was effective in improving the education quality. Here is the link to the data: https://drive.google.com/folderview?id=1-tamSdaEaz9jCHgzpz2F8yiaKBFQAxAF

\subsection{Documentation}

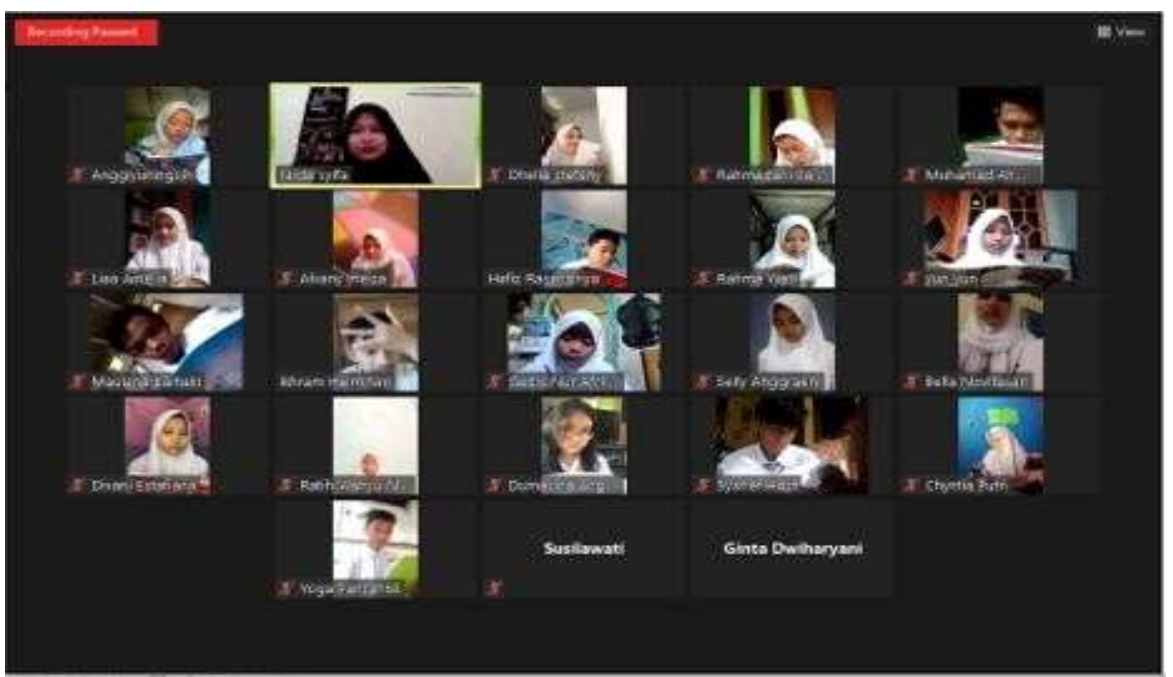

Figure 6. Improving education quality by online learning Classroom

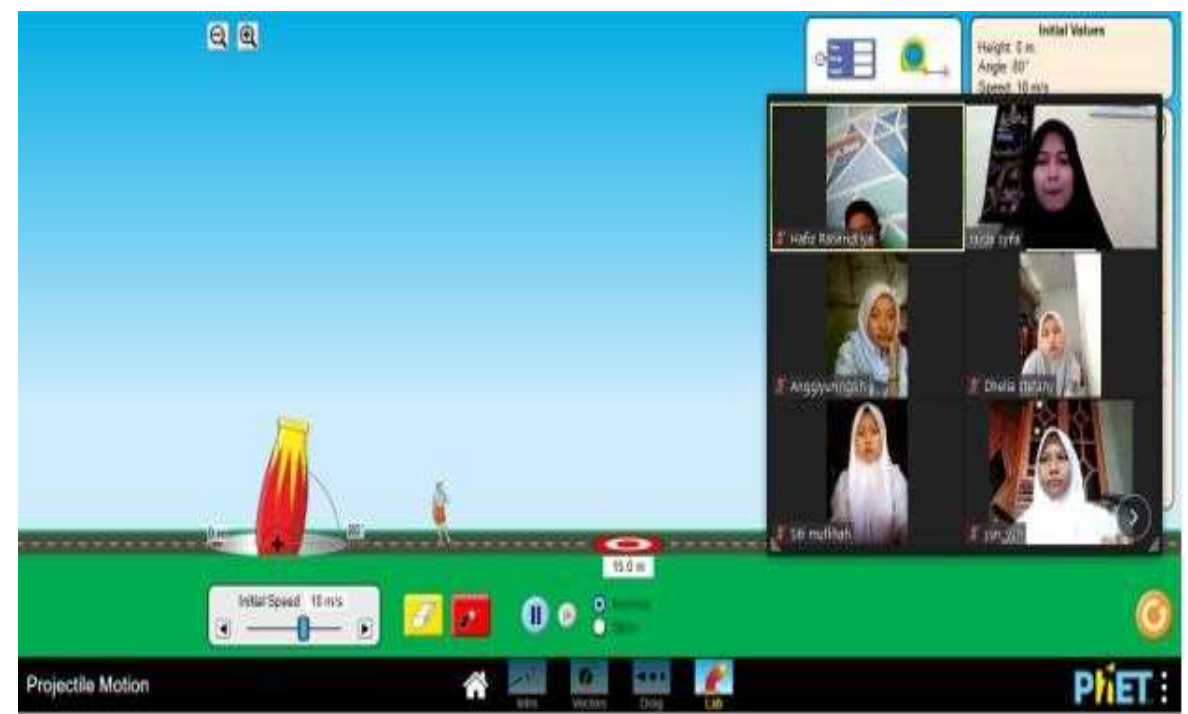

Figure 7. With the POE2WE model, students report their practicum through the website. 


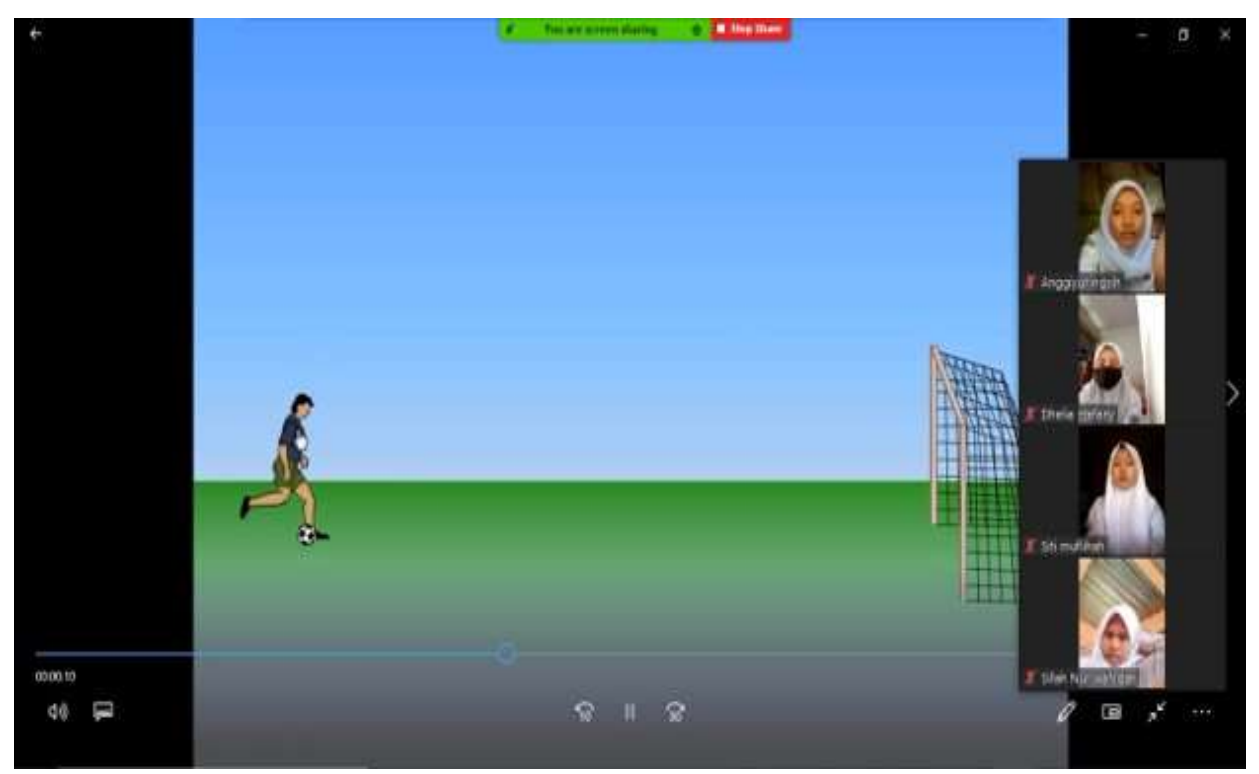

Figure 8. Students take online lesson in parabolic motion.

\section{CONCLUSION}

The conclusion of this study was drawn from two different kinds of analysis, expert validation and participants' test scores. Experts across three different areas i.e. media, material, and learning were found to have a high level of agreement as indicated in $89.40 \%$, $89.31 \%$, and $86.71 \%$ respectively. Effectiveness scores can be showed at average pre-test score of $40.03 \%$ and post-test score of $80.73 \%$ with $\mathrm{N}$-gain score 0.71 (high category). So, it can be concluded that the website and the POE2WE model as implementation of online learning in the Covid-19 era improved the quality of education particularly in learning the parabolic motion.

\section{REFERENCES}

Abdinazarovna, B.S., (2019). Contents of improvement of educational education and problems of education. American Journal of Economics and Business Management, 2(4), pp.74-87.

Adams, W., Clark, A., \& Schneider, K. (2013). Classroom Materials from the Acoustical Society of America. The Physics Teacher, 51.

Apriyanti, N., Razak, R. A., Shaharom, M. S. N., Rahim, S. S. A., \& Halili, S. H. (2020). Needs Analysis of Infographic Media Using Technology for Learning Physics. Malaysian Online Journal of Educational Technology, 8(1), 48-62.

Arikunto. (2015). Prosedur Penelitian Suatu Pendekatan Praktik, Jakarta: Rineka Cipta.

Astuti, F. N., Suranto, S., \& Masykuri, M. (2020, June). The appropriateness of developing the media: experts' validation and students' response of learning media based on augmented reality technology for natural science lesson. In Journal of Physics: Conference Series (Vol. 1567, No. 4, p. 042023). IOP Publishing. 
Azwar, S. (2016). Metode Penelitian. Yogyakarta: Pustaka Pelajar.

Bankole, F. \& Assefa, Z. (2017). Improving the quality of education and research output in Africa is Ethiopian education and research network (ETHERNET). The Journal of Applied Global Research, 10(24), pp.31-51.

Chow, J., \& Carlton, L., (2000). A web-based video digitizing system for the study of projectile motion. American Association of Physics Teachers. Vol. 38.

Hake \& Richard R., (1998). Interactive-engagement versus traditional methods: A sixthousand-student survey of mechanics tests data for introductory physics courses. American Journal of Physics, Volume 66.

Henelsmith, N. (2016). Projectile Motion: Finding the Optimal Launch Angle. Whitman college, $1-38$.

Herdiani, S. (2020). DIGITAL LEARNING USING BLENDED POE2WE MODEL IN ENGLISH LESSON FOR FACING 21ST CENTURY CHALLENGES. Teaching and Learning English in Multicultural Contexts (TLEMC), 4(1), pp.12-24.

Irmayani, H., Wardiah, D. \& Kristiawan, M. (2018). The Strategy of SD Pusri In Improving Educational Quality. International Journal of Scientific \& Technology Research, 7(7), pp.113-121.

Kulkarni, M.A. \& More, H.V. (2020). Role of Information and Communication Tools (ICT) in Higher Educational Institutional System during Covid-19 Lockdown Period. International Journal of Information Technology (IJIT), 6(4).

La Aca, A., Sulisworo, D., \& Maruto, G. (2020). The validity of flipped classroom learning videos on the material of parabolic motion. Universal Journal of Educational Research, 8(10), 4863-4869.

Leontev, M.G., Bondarenko, N.G., Shebzuhova, T.A., Butko, S.S. \& Egorova, L.I. (2018). Improving the efficiency of university management: teacher's performance monitoring as a tool to promote the quality of education. European Research Studies Journal, 21 (2), pp.527-540.

Ma'ruf, M., Handayani, Y., Marisda, D. H., \& Riskawati, R. (2020, January). The needs analysis of basic physics learning devices based on hybrid learning. In Journal of Physics: Conference Series (Vol. 1422, No. 1, p. 012029). IOP Publishing.

Mohamad, A.M.B., Som, H.B.M. and Binti, S. (2016). Impact of Using Website on Online Learning Behavior. International Academic Journal of Humanities, 3(1), pp.170-184.

Nana \& Surahman, E. (2019). POE2WE Model as an Alternative for Learning Physics in Industrial Revolution 4.0 Era. Advances in Social Science, Education and Humanities Research, 397(3), pp.1013-1022.

Nana, S., Akhyar, M., \& Rochsantiningsih, D. (2014). The development of Predict, Observe, Explain, Elaborate, Write, and Evaluate (POE2WE) Learning Model in Physics Learning at Senior Secondary School. Development, 5(19). 
O'Brien, DJ. (2020). Feynman, Lewin, and Einstein Download Zoom: A Guide for Incorporating E- $\quad$ Teaching of Physics in a Post-COVID World. Cornell University, 1-29.

Panigrahi, R., Srivastava, P.R. \& Sharma, D. (2018). Online learning: Adoption, continuance, and learning outcome-A review of literature. International Journal of Information Management, 43, pp.1-14

Parker, A. (2020). Coronavirus (COVID-19): A New Era For Online Education?, Proceedings of SOCIOINT International Conference on Education and Education of Social Sciences, 2020 (7th).

Patresia, I., Silitonga, M. \& Ginting, A. (2020). Developing biology students' worksheet based on STEAM to empower science process skills. JPBI (Jurnal Pendidikan Biologi Indonesia), 6(1), 147-156. DOI: https://doi.org/10.2229/jpbi.v6i1. 10225

Riduwan, \& Akdon. (2013). Formulas and Data in Statistical Analysis. Bandung: Alfabeta.

Serevina, V., Andriana, W., Maynastiti, D., \& Tinura, V. (2020, March). Development of connected massive open online course (CMOOCs) based on multimedia for thermodynamics subject to improve students' self-directed learning outcomes. In Journal of Physics: Conference Series (Vol. 1481, No. 1, p. 012042). IOP Publishing.

Sutarno, S., Setiawan, A., Kaniawati, I., \& Suhandi, A. (2017, September). Pre-service physics teachers' problem-solving skills in projectile motion concept. In Journal of Physics: Conference Series (Vol. 889, p. 012105).

Syakur, A., Fanani, Z. \& Ahmadi, R. (2020). The Effectiveness of Reading English Learning Process Based on Blended Learning through "Absyak" Website Media in Higher Education. Budapest International Research and Critics in Linguistics and Education (BirLE) Journal, 3(2), pp.763-772

Widyastuti, P. D., Mardiyana, M., \& Saputro, D. R. S. (2017, September). An Instructional Media using Comics on the Systems of Linear Equation. In J. Phys. Conf. Ser (Vol. 895, p. 012039).

Wulandari, A., Dasna, I. W., \& Wonorahardjo, S. (2019). The Effectiveness of Contextual-based Instructional Materials of Elements of Group 15 for Inorganic Chemistry. JPP (Jurnal Pendidikan dan Pembelajaran), 26(1), 28-35.

Yuda, Y.P., Azis, M.N.L. \& Kurniawati, I.D. (2019). The Designing of Website-Based Learning Media as an Alternative for Online Learning for Student Practicing at SMKN 1 Sawoo Ponorogo. In Journal of Physics: Conference Series (Vol. 1381, No. 1, p. 012016). IOP Publishing. 